\title{
Professional Development of Educators in Russia in the Paradigm of European Tendencies of LLL
}

\author{
Tatiana Voronchenko*, Marina Fomina, Lyudmila Tatarnikova \\ Faculty of Philology and Mass Communications, Zabaikalsky State University \\ *Corresponding author: tavoronch@mail.ru
}

Received May 21, 2014; Revised August 14, 2014; Accepted August 28, 2014

\begin{abstract}
Life Long Learning, which has acquired great significance in recent years, is an urgent factor in the educational policy of many countries. LLL is considered to be a debatable issue among educators dealing with psychological, methodical and financial aspects of this phenomenon, because of the number of approaches to it. Nevertheless, the concept of LLL presupposes some basic features, such as the presence of the educational environment at any schooling age, the variety of learning trajectories and the established system of improvement of professional skills and abilities. Special importance is given to the professional development of educators, who are not only transmitters and translators of scientific doctrines but are responsible for the formation of spiritual values of the younger generation. There are a number of different programmes in the EU that focus on satisfying the growing needs of sustaining mental fitness and potential employability of people. The field of university education in Russia has both similarities and differences with the learning strategies of the EU. The implementation of LLL technologies among Russian university teachers is present now in three major forms: mastering English, improving professional skills and providing computerized learning environments. It is concluded that professional development of educators occupies one of the most promising areas in the paradigm of LLL, due to the fact that professional qualifications of teachers ensure the quality of the teaching-learning process.
\end{abstract}

Keywords: life-long learning, learning environment, learning trajectory, professional development of educators, system of improvement of professional skills

Cite This Article: Tatiana Voronchenko, Marina Fomina, and Lyudmila Tatarnikova, "Professional Development of Educators in Russia in the Paradigm of European Tendencies of LLL.” American Journal of Educational Research, vol. 2, no. 9 (2014): 759-763. doi: 10.12691/education-2-9-9.

\section{Introduction}

There is an urgent desire in the changing world to correlate our adherence to traditions of the past with challenges of the present day and needs of the younger generation. Though it may be referred to in any sphere of human life, this process demands innovative approaches and learning strategies, especially in the sphere of education. It is widely accepted that knowledge is that which can never be excessive or useless, being the source for individual welfare and a state's prosperity. Obtaining knowledge does not only mean mechanical perception of the sum of established books, formulas or laws. It concerns the molding of a human being's personality at all levels of the educational process from primary schools to universities. The objectives of each learner are very different. It is paradoxical, but educators should be educated throughout the course of their whole life, above and beyond anyone else. Therefore, their professional development perfectly fits the paradigm of Life-long Learning which allows them to preserve their intellectual activity and professional sustainability throughout their entire life.

\subsection{Definition and Basic Principles of LLL}

The term 'Lifelong Learning' is of considerable interest for educators since the verge of the 20-21st centuries, though it was introduced much earlier. Mark K. Smith in the article 'Lifelong Learning' (Encyclopedia of Informal Education) says that the idea of lifelong learning dates back to the times of Plato's Republic. As for the modern period, M.K. Smith gives special attention to the role of such scientists as Basil Yeaxlee, Albert Mansfield, R. H. Tawney and Edward Lindeman, who 'provided an intellectual basis for a comprehensive understanding of education as a continuing aspect of everyday life' [1]. The main idea of LLL presupposes that human life as a whole is made up of constant learning, 'therefore education can have no endings'. Learning is considered to be a natural and compulsory part of any person's existence, and even more than that, a natural right possessed by humans.

In the article, C. Douce stated that 'Life-long learning can mean different things to different people' [2]. These different things may vary greatly, from taking dancing classes to obtaining a doctor's degree. No doubt, adult learners possess different views on the ways and perspectives of realization of their right to obtain knowledge. D.N. Aspin and D.N. Chapman describe a 
number of different definitions of life-long learning. 'Some learners may develop an identity which is tied to and bound-up with learning activities. Others may simply view life-long learning as educational activities that help with life management. Another view is that life-long learning is learning that occurs throughout life. Others may see life-long learning as a set of interrelated ideas that can be used to transform society, enabling its members to become learning resources for its constituents' [3]. It is obvious that regardless of the LLL scenario, this kind of activity is related to a number of urgent problems. These include methodical, psychological and financial problems, as well as the problem of breaking stereotypes often connected with the involvement of adults in the teachinglearning process.

Also, according to the investigations, the role of the learning environment is considered to be one of the most essential aspects of the process. 'Each learner could create their own personal learning environment' [4]. The personal environment can be created both in formal and informal ways by attending regular classes or using resources found on the internet, as well as tools found within any devices that they may have access to. 'Their personal learning environment could be their own laptop computer where each learner could store their files and learning? (sharing?) histories and contacts to other people who share similar interests. Alternatively, a web-based or peer-to-peer application could be used to share opinions and information with other learners' [5].

One more undoubtedly urgent component of LLL is defined by $\mathrm{C}$. Douce as a way to possibly correct a learning plan. 'Each learner may change their learning trajectory at any time.' [6]. The learning trajectory includes mental readiness and certain conditions of the learning environment. These conditions provide the learners with a considerable amount of knowledge, which a person is interested in.

Thus, the process of LLL may be defined as a learning activity for adults not depending on their age and qualification, and an activity possessing variability, flexibility and functioning in the proper learning environment.

\subsection{LLL in the European Union}

The educational policy of the European Union is aimed at 'supporting learning opportunities from childhood to old age', as it is proclaimed on the site of the European Commission on education. One of the most successful providers of LLL opportunities is The Education, Audiovisual and Culture Executive Agency (EACEA). The LLL programme of the Agency procures several subsections which are devoted to different stages of education; Comenius for schools, Erasmus for higher education, Leonardo da Vinci for vocational education and training and Grundtvig for adult education. The latter was launched in 2000 and is now part of the overarching Lifelong Learning Programme. 'Grundtvig aims to provide adults with ways to improve their knowledge and skills, keeping them mentally fit and potentially more employable.

It not only covers learners in adult education, but also the teachers, trainers, and educational staff and facilities that provide these services. These include relevant associations, counselling organisations, information services, policy-making bodies and others involved in lifelong learning and adult education at local, regional and national levels, such as NGOs, enterprises, voluntary groups and research centres' [7].

As it follows from the description, the essential purpose of the program is related to the potential employment of people preserving their competitive abilities as long as possible. It is very important that the program's name was taken after Nikolaj Frederik Severin Grundtvig (17831872), the Danish pastor and educator, who is known for his theoretical thoughts and practical achievements in the field of adult education. One of his most essential and highly regarded ideas was the idea of democratization of learning and making it closer to the practical needs of common, non-scientific people. Rather than educating learned scholars, Grundtvig believed the university should train its students for active involvement into society and popular life.

Grundtvig programs of UE include several subprograms, such as Grundtvig Multilateral Projects, Grundtvig Multilateral Networks, and Grundtvig Accompanying Measures.

Educational institutions from different participating countries which work together, commit to Grundtvig Multilateral Projects integrating knowledge and experience, 'in order to achieve concrete and innovative results/products, like courses aimed at enhancing the quality of the provision, with indisputable European value' [8]. In many cases, this involves piloting experiences in strategic areas and producing teaching products of high quality. These projects also seek to strengthen the European dimension in the field of adult learning.

Grundtvig Multilateral Networks' aim is 'to strengthen the link between the various 'actors' involved in adult education in the broadest sense, to improve the quality, European dimension and visibility of activities or issues of common interest in the field of adult learning and to help make lifelong learning opportunities more widely known and available to citizens' [9]. Grundtvig Accompanying Measures sub-program appears as a supporter of various activities which, though not eligible under the main actions of the Grundtvig Programme, clearly contribute to achieving its objectives.

The great advantage of Grundtvig Programme is that it makes many learning trajectories available for adult learners, including those who want to maintain the professional sustainability in the field of higher education.

\subsection{LLL of University Educators in Russia}

In the report 'Developing the Conception of the Lifelong Learning in the Academic Discourse of Russia' presented at the $2^{\text {nd }}$ Cyprus International Conference on Educational Research, Tatiana Voronchenko and Svetlana Chugunova made an observation of the milestones of appearance and promotion of the Conception of LLL in contemporary Russia. The major role in their report is given to the importance of adult learners studying English, especially university teachers, as an integral part of their professional development. This is because as they say; 'the majority of scholars and scientists in the Russian provincial universities lack the ability to communicate 
their own ideas and theories internationally, they miss the opportunity to become competitive at the world research market'. (Ataturk Teacher Training Academy, Lefcosa, North Cyprus, Feb 13-15, 2013; oral presentation)

We define several aspects of implementation of the technology of LLL among Russian university teachers. It is implemented in three major forms: learning English, improving professional skills and using computers in the teaching process, thus providing computerized learning environments.

The idea of significance of learning foreign languages, which enables Russian scholars to enter international educational space, has been purely expressed in the open letter of the president of St. Petersburg State University, Dean of Faculty of Philology Lyudmila Verbitskaya and Vice Rector Sergey Bogdanov to the director of the Institute of Russian Literature. According to the letter, all teaching programs will necessitate that graduates of all specialties receive international certificates 'on minimum level of mastering the English Language which corresponds to European B 2 level' [10]. Also the authors of the letter emphasize the idea to develop masters' programs that guarantee graduates two diplomas: the first in the native language, the second in a foreign language, primarily English.

Thus, the fact, that many Russian university educators don't speak English adequate for professional communication and are not able to transmit their ideas and exchange the results of their creative work with colleagues from different countries needs special attention and demands special consideration in modernizing educational system in Russia. We attempt to solve this problem at Zabaikalsky State University.

The second aspect of professional development for educators in the paradigm of LLL is related to the system of Improvement of Professional Skills (повьичение квалификаиии). This is the development of such qualities of university teachers which allows them to keep up with the newest tendencies in the sphere of their scientific specialty. It is necessary to note that this idea is not so original at all; it has a long history closely connected with the history of higher education in the Soviet Union. According to Big Soviet Encyclopedia 'Soviet educational institutions had a goal to prepare highly skilled professionals mastering both theoretical and practical abilities ... and improve the skills of teaching staff in higher and secondary educational institutions, as well as specialists with higher education employed in the respective industries' [11].

Faculties of Improvement of Professional Skills (Факультеты повыщения квалификации) were founded in all top Soviet universities and institutes of different branches of economy. 'During the 50's and 60's there was a flourish of rocket and space technology, nuclear physics, chemistry, electronics, radio engineering, automation, and other fields of science and technology, which required retraining and skills development that affected the system of higher education. Furthermore, it became apparent that the results obtained in universities rapidly turn out to be outdated with the appearance of new, previously unknown trends in science and technology' [12]. When creating FIPSs the authorities had to solve all the organization and pedagogical issues: the forms and methods of training teachers, the choice of skills' directions, establishing links with many universities in the country for official journeys of teachers from provincial cities to study at the leading universities, institutes and academies.

Unfortunately, the current system of organizing and conducting training for teaching staff, effectively ensuring the improvement of professional and pedagogical training of teachers all over the country for many years since the mid-1990s, was destroyed when funding of higher education was brought to a close. Faculties of Improvement of Professional Skills had to exist and teach only on the basis of faculty members' enthusiasm. The members had to maintain a scientific and pedagogical level almost without the necessary internal and external support. Nowadays, we observe the revival of this system due to the state's support and initiative of universities' executives who realize the importance of professional education as a life-long process, providing both personal development of educators and the interests of the country's economy.

Currently, the improvement of professional education for higher school teachers is in the center of practical and scientific discussion; which is reflected in a number of monographs, articles in pedagogical journals and materials of special conferences. University teachers exchange experience of putting innovative approaches into practice during the conferences. Unfortunately, few of the approaches are known to their colleagues abroad because of the reason previously mentioned.

We suppose that it is possible to define two major streams of innovations: organizational and methodical. Organizational approaches concern new innovative forms of educational process, such as module technology of training teaching stuff (staff?). This is aimed at the optimization of the teachers' schedule and fitting different activities into their professional development more efficiently. In the past, if a university teacher wanted to improve their professional skills, it was necessary to leave work and home and to go to famous universities in big cities, mostly Moscow or St. Petersburg for a period of time (from one to four months). Now, positional universities invite specialists from leading educational institutions in Russia and abroad and allow their members to improve their qualification without financial costs and the loss of teaching time. Also, the level of professional experience and individual characteristics of teachers are taken into account to individualize programs as much as possible.

Methodical innovations deal with the content of education and its quality. Mostly, they are related to such teaching technologies which deal with the changing role of a teacher in the globalized world. (See, e.g. Tracing Changes in Role and Professional Identities of Teachers ....p. 25). One of the main ideas is that the teacher is not a source of information any more. Instead, he or she should be a guide across the field of knowledge. This idea is a dominant one in the methodological paradigm of contemporary educational process. Integration of Information and Communication Technologies (ICT) challenge the role and professional identities of teachers. This is described by N. Alekhina and G. Korableva in the article 'Innovations in Educational Process in the System of Improvement of Professional Skills of University teachers (in Russian). 'In current circumstances a teacher does not just transfer 
knowledge; there is an urgent need to formation of students' ability of self-learning, the development of skills to apply their theoretical knowledge into practice' [13]. Thus, a special attention is given to such methods of teaching which develop students' personal characteristics and their professional competence (projects, professional Olympiads, banks of innovations, participation in solving particular problems of industrial enterprises, etc). In other words, teachers' methods aim at promoting advanced learning abilities, especially critical thinking.

The relevance of programs is determined by the demands of society and the market for new knowledge, due to Russia's transition to innovative development. 'The basic principle of managing educational process is the flexibility and the invariance of professional training. The educational process is based on individual-oriented curriculum that best meets the needs of teachers and the interests of their chairs' [14].

The development of teachers' professional skills at Zabaikalsky State University corresponds to the majority of these demands. In recent years our teaching staff has had an opportunity to widen their competencies in the following areas: Scientific Research Activity of a Higher School Teacher, 2009 (Научно-исследовательская деятельность преподавателя высшей школь); Educational Strategies and Technologies in Pedagogical Education, 2010 (Образовательные стратегии и технологии в педагогическом образовании); Didactics and Competence in Professional Activity, 2012 (Дидактика и компетентность в профессиональной деятельности) and others. In general, the total amount of different programs aimed at the development of professional skills of university teaching staff reaches twenty three programs of different specialties, both in technical and humanitarian spheres.

The third aspect of professional development of educators in the paradigm of LLL is connected with the introduction of computer technologies into the process of teaching. It is not a secret that representatives of an older generation of teachers in Russia have a certain degree of fear of computer technologies and its wider implementation into the learning process, in order to meet the demands of the digital age. Computers are often seen more as a means of entertainment or a source of information, but their role in teaching process is underestimated. Nonetheless, according to the Working Document of Commission of the European Communities, "The use of ICT to support innovation and lifelong learning for all - A report on progress (Brussels, 2008)”, 'The emerging technologies with enhanced networking capabilities and personalization create opportunities for new mobile learning environments with phones, game consoles and MP3 players. The convergence of digital media will enable developments such as pod-casts, digital TV and radio and interoperability across platforms. Furthermore, new creative approaches, such as simulations, gaming, virtual reality and immersive environments, offer learning tools from early school years to specialized professional training' [15]. Educational use of digital content has a good perspective in projects that bring together the technological, pedagogical and organizational aspects of teaching. Therefore, teachers themselves should be properly trained for it.
We shall make a conclusion that professional development of educators occupies one of the most promising areas in the paradigm of LLL. This important component enables the integration of different levels and forms of education to more flexible learning paths for a particular individual and allows professional education to become truly continuous for one's entire life. As Professor John Field points out while promoting Lifelong Learning, 'We learn new facts, skills, ideas and emotional capacities simply by virtue of enrolling with that permanently instructive institution, the University of Life. In this broad meaning of the term, you cannot stop yourself from being a lifelong learner. It covers pretty much everything - and rightly so' [16].

\section{Summary}

To sum up, LLL in Russia is characterized by a number of specific features, which both differ from and coincide with European tendencies. First of all, the quantity of common people involved in the organized process is limited by the above-mentioned behavioral stereotypes on age. Secondly, the significant priority is given to professional development of employees because of the necessity of succeeding in professional competition.

LLL in Russia possesses specificity of general priorities and strategies. The professional development of educators acquires a significant role because the professional qualifications of teachers ensure the quality of the teaching-learning process. The major priority in this sphere should be given to learning English and promoting further implementation of information technologies. Russian educators of all levels are working on integration into the European paradigm of LLL, paying attention to its advantages such as variability, flexibility and providing a more successful learning environment.

The question remains whether or not it brings advantages to the state. It is obvious that personal freedom and the right to study correspond to a democratic state's policy, if a state like contemporary Russia is intended to be integrated into the world's educational space.

\section{References}

[1] Smith, M.K. (2001). Lifelong learning. Available: http://www.infed.org/lifelonglearning/b-life.htm. [Accessed May 2, 2014].

[2] Douce, C. (2010).Considering the dimensions of life-long learning tools. In: Proceedings of the Ten Competence Open Workshop, 10-11 Apr 2010, Madrid, Spain.

[3] Aspin, D.N., Chapman, J.D. (2007). Lifelong learning: concepts and definitions. In Aspin, D.N. Philosophical Perspectives on Lifelong Learning, Springer, p. 19-38, 2007.

[4] Johnson, M., Liber, O., Wilson, S., Sharples, P., Milligan, C., Beauvoir, P. (2006). Mapping the Future: The personal learning environment reference model and emerging technology. Proceedings of ALT-C, p. 182-191.

[5] Koper, R., Giesbers, B., van Rosmalen, P., Sloep, P., van Bruggen, J., Tattersall, C., Vogten, H., Brouns, F. (2005). A design model for lifelong learning networks. Interactive Learning Environments, 13(1), 2005.

[6] Johnson, M., Liber, O., Wilson, S., Sharples, P., Milligan, C., Beauvoir, P. (2006). Mapping the Future: The personal learning environment reference model and emerging technology. Proceedings of ALT-C, p. 182-191. 
[7] Grundtvig Programme (2013). Available: http://eacea.ec.europa.eu/llp/grundtvig/grundtvig_en.php. [Accessed April 30, 2014].

[8] Grundtvig Multilateral Projects (2013). Available: http://eacea.ec.europa.eu/llp/grundtvig/grundtvig_multilateral_proj ects_en.php. [Accessed April 30, 2014].

[9] Grundtvig Multilateral Networks (2013). Available: http://eacea.ec.europa.eu/llp/grundtvig/grundtvig_multilateral_net works_en.php. [Accessed April 30, 2014].

[10] Verbitskaya L., Bogdanov S. (2013). Otkrytoye pis'mo Direktoru Instituta russkoy literatury RAN [Open Letter to Director of Institute of Russian Literature]. Available:

http://www.pushkinskijdom.ru/LinkClick.aspx?fileticket=6K4dzlp 9A-Y\%3d\&tabid=36. [Accessed Feb. 15, 2014].

[11] Narodnoye obrazovaniye (Bol'shaya sovetskaya entsiklopediya, SSSR) (1978). [People's Education (Big Soviet Encyclopedia, USSR)]. Available:

http://slovari.yandex.ru/ книги/БСЭ/СССР.\%20Народное\%20об разование/ [Accessed Feb. 18, 2014].

[12] Moskovskiy aviatsionnyy institut. 45 let organizatsii povysheniya kvalifikatsii prepodavateley v MAI (2014). [Moscow Aviation Institute. Article on 45th Anniversary of Faculty of Improvement of Professional Skills of Teachers]. Available: http://www.mai.ru/ [Accessed Jan. 26, 2014].

[13] Alekhina N.V., Korableva G.V. (2011). Innovatsii v obrazovatel'nom protsesse sistemy povysheniya kvalifikatsii prepodavateley vysshey shkoly. [Innovations in Educational Process in the System of Improvement of Professional Skills of University Teachers]. Contemporary Scientific Technologies Journal. 2011 (1). P. 108-109.

[14] Sankt-Peterburgskiy natsional'nyy issledovatel'skiy universitet informatsionnykh tekhnologiy, mekhaniki $i$ optiki. Fakul'tet povysheniya kvalifikatsii prepodavateley (2014). [ST. Petersburg National Research University of Information Technologies, Mechanics and Optics. Faculty of Improvement of Professional Skills of Teachers]. Available:

http://www.ifmo.ru/faculty/10/fak_10.htm. [Accessed May 2, 2014].

[15] Commission of the European Communities. Commission Staff Working Document. The use of ICT to support innovation and lifelong learning for all. A report on progress. (2008). Available: http://www.europarl.europa.eu/registre/docs_autres_institutions/co mmission_europeenne/sec/2008/2629/COM_SEC(2008)2629_EN. pdf. [Accessed April 30, 2014].

[16] Field, J. Lifelong Learning and the New Educational Order. Trentham Books. 2000. P. vii -viii. 